Article

\title{
Experimental Testing of Combustion Parameters and Emissions of Waste Motor Oil and Its Diesel Mixtures
}

\author{
Dragiša Đorđić $^{1, *}$, Milan Milotić ${ }^{2}$, Zoran Ćurguz ${ }^{2}$, Slavko Đurić ${ }^{2}$ and Tihomir Đurić ${ }^{2}$ \\ 1 Faculty of Ecology, Independent University of Banja Luka, 78000 Banja Luka, Bosnia and Herzegovina \\ 2 Faculty of Transport and Traffic Engineering, University of East Sarajevo, \\ 74000 Doboj, Bosnia and Herzegovina; milan.milotic@sf.ues.rs.ba (M.M.); curguzzoran@yahoo.com (Z.Ć.); \\ slavko.djuric@sf.ues.rs.ba (S.Đ.); tihomir.djuric@sf.ues.rs.ba (T.Đ.) \\ * Correspondence: zastitad@gmail.com; Tel.: +387-65-738-060
}

check for updates

Citation: Đorđić, D.; Milotić, M.;

Curguz, Z.; Đurić, S.; Đurić, T.

Experimental Testing of Combustion Parameters and Emissions of Waste Motor Oil and Its Diesel Mixtures. Energies 2021, 14, 5950. https:// doi.org/10.3390/en14185950

Academic Editor: Octavio Armas

Received: 3 August 2021

Accepted: 15 September 2021

Published: 18 September 2021

Publisher's Note: MDPI stays neutral with regard to jurisdictional claims in published maps and institutional affiliations.

Copyright: (c) 2021 by the authors. Licensee MDPI, Basel, Switzerland. This article is an open access article distributed under the terms and conditions of the Creative Commons Attribution (CC BY) license (https:// creativecommons.org/licenses/by/ $4.0 /)$.

\begin{abstract}
The production of hydrocarbon fuel from waste engine oil is an excellent way to produce alternative fuels. The aim of the research in this paper is obtaining fuel with a mixture of waste engine oil (WMO) and diesel fuel that can be used as an alternative fuel for internal combustion engines and low power heat generators. With this goal in mind, tests were conducted to estimate the combustion parameters and emissions at a low heat output of $40 \mathrm{~kW}$. Waste motor oils (WMO) and four of its diesel mixtures were used, varying in weight from 20\% WMO to 50\% WMO. Test results were analysed and compared with diesel fuel. Higher $\mathrm{NO}, \mathrm{CO}$ and $\mathrm{CO}_{2}$ emissions were determined for WMO and its mixtures compared to diesel fuel. The flue gas temperature in the kiln was high for all WMO and diesel blends, which indicates the efficiency of the input energy. The absorption of flue gases in the scrubber with distilled water showed higher presence of sulphates, sulphides, nitrates and nitrites compared to allowable values.
\end{abstract}

Keywords: combustion; parameters; diesel fuel; waste motor oil; emission

\section{Introduction}

Increasing energy consumption, strict emission standards and consumption of oil resources have led a large number of researchers to explore the possibility of using alternative fuels for internal combustion engines and heat generators. Waste oils present a serious problem for the environment due to their disposal and are considered useful energy sources due to their high calorific value.

Motor oils have multiple roles in internal combustion engines. They lubricate the engine, reduce friction and wear of its moving parts, ensure good cylinder-piston assembly sealing, protect the engine from corrosion, ensure efficient engine cooling, keep the engine in a clean and functional state and prevent the formation of sediment and impurities on engine parts. During use, there are changes in the initial characteristics and contamination with different materials (water, products fraying and other impurities) so that, after a certain period of use, they do not satisfy the lubrication requirements and must be replaced with new ones. Legal regulations concerning waste disposal are increasingly violated in Bosnia and Herzegovina, and that especially applies to the disposal of motor oil (WMO) waste. Inadequate disposal of WMOs can lead to great environmental damage and ripening of soil and water pollution. In order to protect the environment, the following activities should be undertaken:

- Reduce the amount of WMO for lubrication (by extending the service life of lubricating oil using rapidly biodegradable lubricating oils);

- Organize WMO collection (oil waste collection is part of the overall waste management process);

- Recycling of WMOs (conversion of waste lubricating oils into commercially usable products, for example, refining processes to base oils). 
In addition to the negative environmental impact, WMOs also have caloric properties (energy value), so when mixed with other fuels such as diesel fuel, they can be used as fuels for agricultural machinery and individual combustion plants and for the operation of larger marine engines and various combustion plants [1]. They could also be used in various branches of process engineering (heating plants, dryers, cement plants, brick production, asphalt bases, etc.). There is insufficient data in the literature on the feasibility of using WMO and its blends with diesel as fuel in a higher-power heat generator. Recently, many researchers have been exploring the possibility of using waste cooking oil and waste transformer oils as an alternative fuel for diesel engines [2-4]. The studies were performed on a single cylinder four-stroke $4.4 \mathrm{~kW}$ and $5.7 \mathrm{~kW}$ maximum cylinder pressure of about $8.6 \times 10^{6} \mathrm{~Pa}$ [5-10]. Many researchers [11-16] have been exploring the possibility of using various types of waste oils (transformer, palm, rapeseed, sunflower, various lubricants) and their mixtures as an alternative fuel in internal combustion engines. They obtained similar results, i.e., waste oils and their mixtures can be used in internal combustion engines. It has also been shown that engine performance has improved in terms of fuel economy and environmental impact. There is insufficient data in the cited literature on the environmental impact of the composition of flue gas resulting from the combustion of $\mathrm{WMO}$ and its mixtures with diesel fuel.

In this study, an attempt was made to evaluate the combustion and emission characteristics using $\mathrm{WMO}$ and its mixtures in a $40 \mathrm{~kW}$ furnace at atmospheric pressure with respect to diesel fuel combustion. WMO can be used in $40 \mathrm{~kW}$ heat generators and can reduce problems relating to the protection of the environment. This is especially important for the development of a circular economy that uses renewable energy sources, which is especially important for Bosnia and Herzegovina, a highly resource-dependent country.

\section{Materials and Method}

\subsection{Motor Oil}

WMOs are all mineral or synthetic oils that are unusable for the purpose for which they were originally intended, such as: engine lubrication, engine cooling, friction reduction on moving engine parts, protecting the engine from corrosion and more.

Mineral motor oils are obtained by adding certain additives to the base mineral oil to achieve its desired physical and chemical properties. There are various additives such as: various enhancers for viscosity, oxidizing inhibitors, dispersants, high pressure additives, antifoaming agents, emulsifiers and de-emulsifiers. Due to their low prices, they are the most represented on the market.

Synthetic motor oils are derived from artificially produced base oils with additives to improve their chemical and physical properties. Synthetic motor oils are much more expensive than mineral oils. Their application is justified only in areas where there are cooling and lubrication problems that cannot be technically solved by the use of conventional lubricants. Hydrocarbon and ester synthetic lubricants are most prevalent in motor oils.

\subsection{Physical and Chemical Properties of WMO}

WMO used as fuel in this test was collected in the units of Electric Power Company "Elektro-Bijeljina" a.d. Bijeljina, Bosnia and Herzegovina. Diesel fuel was purchased at the gas station of the company "OPTIMA GRUPA" d.o.o. Banja Luka, Bosnia and Herzegovina. This is why, for experimental research purposes, WMO is mixed with diesel fuel in different mass ratios, 20\% WMO and 80\% diesel fuel, 25\% WMO and 75\% diesel fuel, 33\% WMO and $67 \%$ diesel fuel and 50\% WMO and 50\% diesel fuel, designated as WMO20, WMO25, WMO33 and WMO50, respectively. The composition of the mixture of WMO and diesel fuel in the considered mass ratios was determined using the expression

$$
X(\text { mixture })=x X(\mathrm{WMO})+(1-x) X(\text { diesel fuel }), \%,
$$


where:

$X$ (mixture) - the mass fraction of component $X$ in the mixture, $\%$

$X(\mathrm{WMO})$-mass fraction of component $X$ in $\mathrm{WMO}, \%$

$X$ (diesel fuel) - mass fraction of component $X$ in diesel fuel, $\%$

$x$-mass fraction of WMO in the mixture $(0.20,0.25,0.33,0.50), \mathrm{kg} \mathrm{kg}^{-1}$

$1-x$ - mass fraction of diesel in the mixture, $\mathrm{kg} \mathrm{kg}^{-1}$.

The thermal power of the WMO-diesel fuel mixture was determined using the expression [17]

$$
H_{d}=33,900 C+121,400(H-O / 8)+10,460 S-2510 W, \mathrm{~kJ} \mathrm{~kg}^{-1}
$$

where:

$\mathrm{C}, \mathrm{H}, \mathrm{O}, \mathrm{S}, \mathrm{W}$-mass fraction of carbon, hydrogen, oxygen, sulphur and moisture in the mixture, $\mathrm{kg} \mathrm{kg}^{-1}$.

Comparisons of the chemical composition of WMO and diesel are shown in Tables 1 and 2. Table 1 shows much higher values of the mass fractions of $\mathrm{S}, \mathrm{W}$ and $\mathrm{A}$ in WMO compared to the values for diesel fuel.

Table 1. Chemical properties of the WMO and diesel fuel [18].

\begin{tabular}{ccc}
\hline Description (Mas. \%) & Diesel Fuel & WMO \\
\hline C & 85.76 & 85.47 \\
H & 14.00 & 12.64 \\
N & 0.20 & 0.12 \\
S & 0.0043 & 0.15 \\
W & 0.0080 & 0.52 \\
A & 0.0077 & 1.10 \\
O by difference & 0.0200 & 0.00 \\
\hline
\end{tabular}

Table 2. Fuel properties of test fuel.

\begin{tabular}{|c|c|c|c|}
\hline Fuel & $\begin{array}{c}\text { Fuel Ratio } \\
\text { (Mas. \%) }\end{array}$ & $\begin{array}{c}\text { Density } \\
\left(\mathrm{kg} \mathrm{m}^{-3}\right)\end{array}$ & $\begin{array}{l}\text { Lower Thermal } \\
\text { Power }\left(\mathrm{kJ} \mathrm{kg}^{-1}\right)\end{array}$ \\
\hline Diesel fuel & $0 / 100$ & 821.30 & 46,066 \\
\hline WMO20 & $20 / 100$ & 827.25 & 45,717 \\
\hline WMO25 & $25 / 100$ & 828.75 & 45,630 \\
\hline WMO33 & $33 / 100$ & 831.16 & 45,490 \\
\hline WMO50 & $50 / 100$ & 836.33 & 45,194 \\
\hline WMO & $100 / 0$ & 851.92 & 44,322 \\
\hline
\end{tabular}

A special fact is that the use of pure WMO is made difficult due to its density and viscosity (Table 2).

\section{Experimentation}

The scheme of the laboratory facility used in this research and the list of measurement sites are shown in Figure 1. 


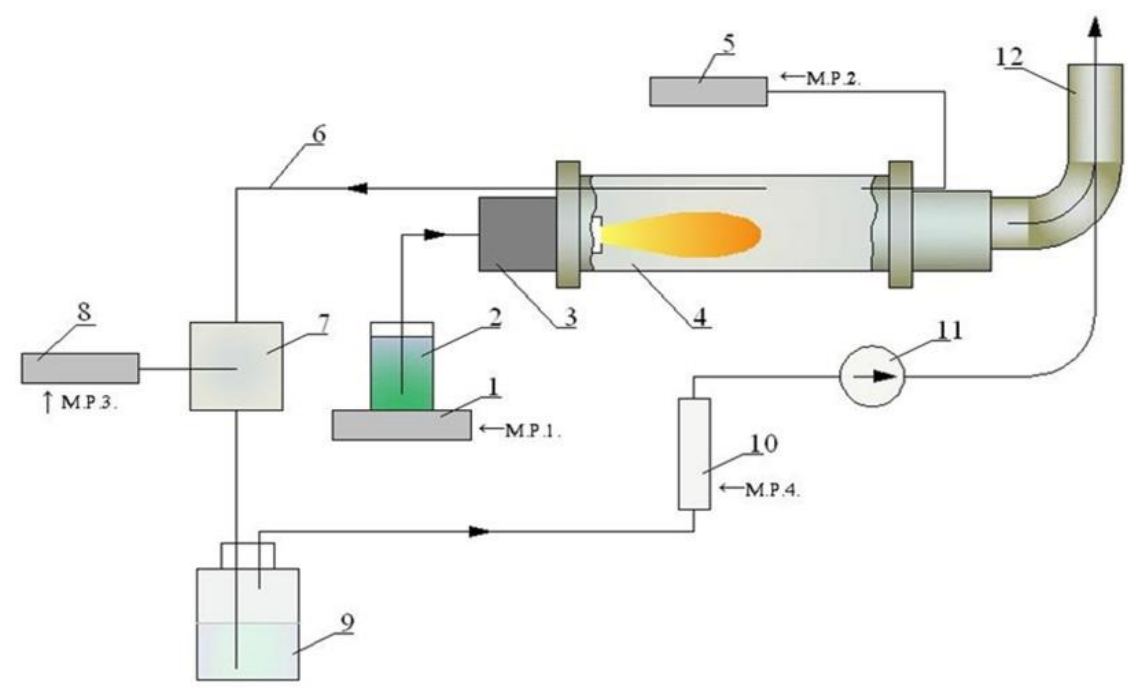

Figure 1. Experimental setup: (1) fuel consumption measuring device; (2) burette; (3) burner; (4) rotary kiln; (5) temperature indicator; (6) partial flue gas flow; (7) smoke analysis bottle; (8) smoke analyser; (9) flue gas washing bottle; (10) flue gas flow meter; (11) pump; (12) exhaust pipe; (M.P.1.); fuel consumption; (M.P.2.); flue gas temperature in the rotary kiln; (M.P.3.); flue gas analysis $\left(\mathrm{O}_{2}, \mathrm{CO}\right.$, $\mathrm{CO}_{2}, \mathrm{NO}, \mathrm{t}$ ); (M.P.4.); flue gas volumetric flow rate.

Diesel combustion parameters and WMO-diesel fuel blend parameters were tested in the various mass ratios, and it was performed in a rotary kiln (Figure 1). WMO and its diesel fuel mixtures were well mixed to give a homogeneous stable mixture. Prior to combustion, samples of various fuel mixtures were held in an open-air atmosphere (2). Mass consumption of fuel was measured directly by a scale (1). The fuel from the mensuration was injected using a burner (3) and burned in a rotary kiln (4). Using a pump (11) located at the end of the sampling line, a partial flow of flue gas (6) was sampled, and in the vessel (7), the composition of the flue gas $\left(\mathrm{CO}, \mathrm{CO}_{2}, \mathrm{O}_{2}, \mathrm{NO}\right)$ as well as the coefficient of excess air and the temperature of the sampled gas were determined. After determining the composition of the flue gas sampled, the flue gas was passed through a flue gas rinse with distilled water (9) to remove sulphate. The gas flow was measured using a rotameter (10). In order to obtain reliable results of testing the parameters of the fuel combustion process, the experiment was repeated four times for each fuel used. The results were compared, and no major discrepancies were observed. Values of standard deviation (S) and variation coefficient $(\mathrm{Cv})$ of measurement results for gaseous components $\mathrm{NO}, \mathrm{CO}$ and $\mathrm{CO}_{2}$ caused by combustion of fuel D4 and its mixtures with WMO are shown in Figures 2-4.

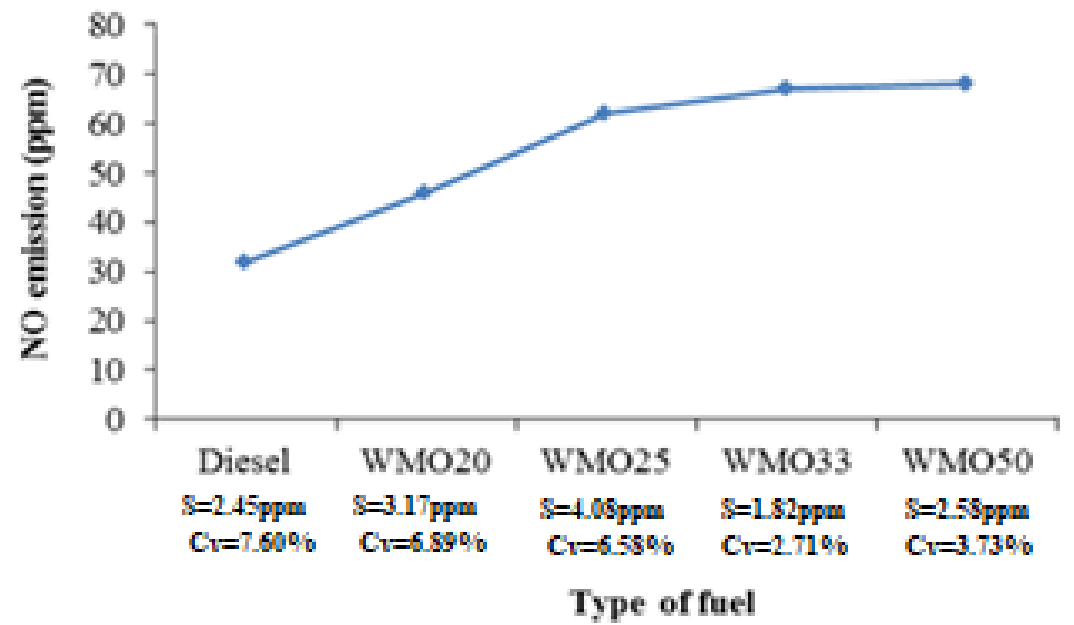

Figure 2. NO variations for different fuels. 


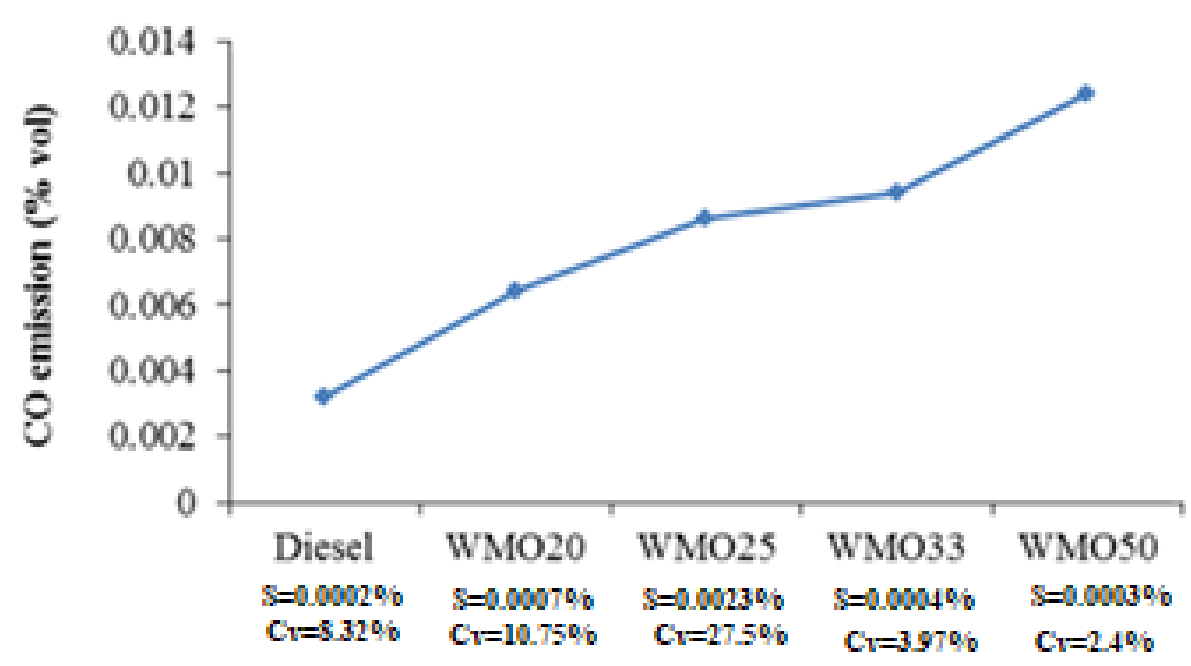

Type of fuel

Figure 3. CO variations for different fuels.

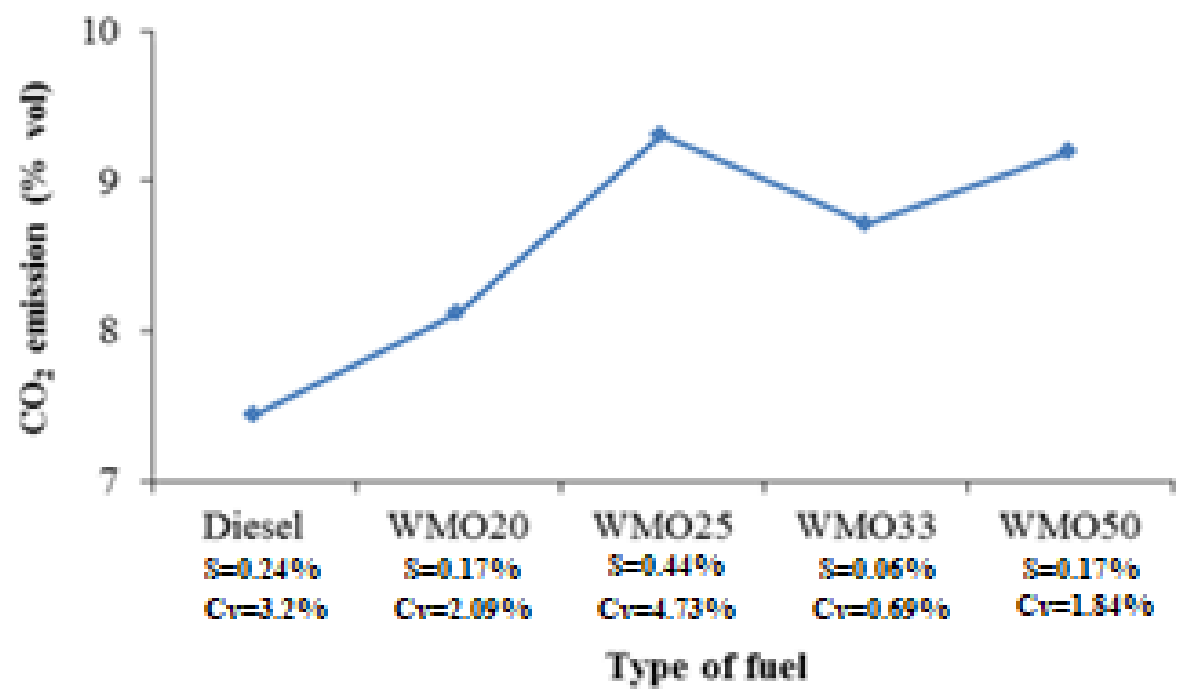

Figure 4. $\mathrm{CO}_{2}$ variations for different fuels.

During the experimental testing of the combustion process of diesel fuel and WMO diesel fuel mixture, the following measuring instruments were used: digital scale QZ-161 for measuring fuel consumption (M.P.1.); measuring range: 0-5000 g, measurement error $\pm 1 \mathrm{~g}$; WL2V burner $\mathrm{kg} \mathrm{h}^{-1} 1.6-3 \mathrm{~A}^{-1}$; digital temperature gauge Testo 925 with type $\mathrm{K}$ probe (NiCr-Ni) (M.P.2.); measuring range: $50-1000{ }^{\circ} \mathrm{C}$, measurement error $\pm 0.2 \%$; and Testo 330-2 LL gas analyser to measure the composition of the sampled gas $(\mathrm{CO}, \mathrm{NO}$, $\mathrm{O}_{2}, \mathrm{CO}_{2}, \lambda$, t) (M.P.3).

\section{Results and Discussion}

\subsection{Combustion Analysis}

Fuel consumption during the test ranged from $2.09 \mathrm{~kg} \mathrm{~h}^{-1}$ for diesel fuel to $3.50 \mathrm{~kg} \mathrm{~h}^{-1}$ for WMO50. The increased fuel consumption of the WMO20, WMO25, WMO33 and WTO50 relative to diesel fuel was compared to the diesel fuel density due to the higher density of the considered fuels (Table 3). 
Table 3. Medium measured values of fuel combustion parameters.

\begin{tabular}{cccccc}
\hline \multirow{2}{*}{ Parameter } & \multicolumn{3}{c}{ Type of Fuel } \\
\cline { 2 - 5 } & Diesel & WMO20 & WMO25 & WMO33 & WMO50 \\
\hline Mass flow of fuel $\left(\mathrm{kg} \mathrm{h}^{-1}\right)$ & 2.09 & 2.63 & 2.95 & 2.87 & 3.50 \\
Gas temperature in a rotary kiln $\left({ }^{\circ} \mathrm{C}\right)$ & 589 & 626 & 642 & 684 & 719 \\
Sampling gas temperature $\left({ }^{\circ} \mathrm{C}\right)$ & 198 & 175 & 167 & 157 & 9.48 \\
Oxygen content in the flue gas $(\%)$ & 10.90 & 10.25 & 1.73 & 1.83 & 9.20 \\
Coefficient of excess air & 2.07 & 1.95 & 1.06 & 1.10 & 1.08 \\
Volume flow of sampled gas $\left(\mathrm{m}^{3} \mathrm{~h}^{-1}\right)$ & 1.10 & 1.07 & & & \\
\hline
\end{tabular}

This resulted in a reduction in the excess air ratio from 2.07 for diesel to 1.74 for WMO50. The sampled gas flow during the test was kept approximately constant and ranged from $1.06 \mathrm{~m}^{3} \mathrm{~h}^{-1}$ to $1.10 \mathrm{~m}^{3} \mathrm{~h}^{-1}$.

The flue gas temperature in the rotary kiln ranged from $589^{\circ} \mathrm{C}$ to $719^{\circ} \mathrm{C}$, and the exchange temperature (gas sampling temperature) ranged from $157^{\circ} \mathrm{C}$ to $214^{\circ} \mathrm{C}$. We measured higher flue gas temperatures in the case of mixing $\mathrm{WMO}$ with diesel fuel compared to diesel fuel with higher WMO density results, and WMO measurement was higher than diesel density, resulting in higher heat release rates (Figure 5).

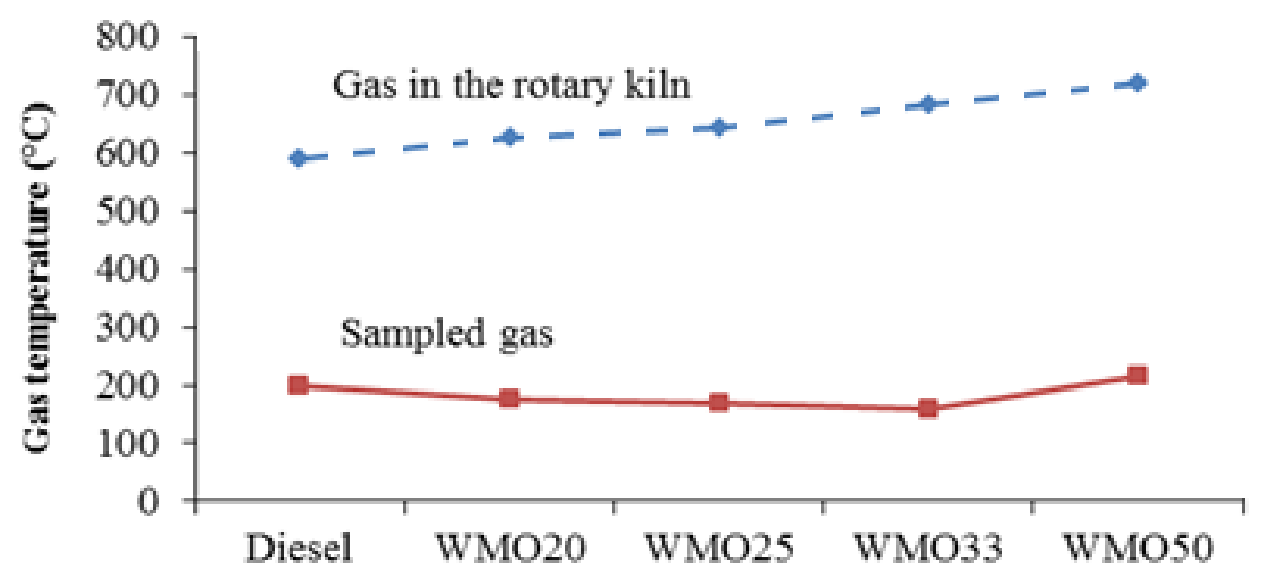

Type of fuel

Figure 5. Flue gas temperatures for different types of fuel.

\subsection{Emission Parameters}

\subsubsection{Nitric-Oxide (NO) Emission}

Variations in NO emissions from diesel fuel combustion, WMO-diesel fuel blends are shown in Figure 3. It can be observed that $\mathrm{NO}$ emissions for WMO diesel mixtures are higher than $\mathrm{NO}$ emissions from diesel combustion. Higher NO emissions are the consequence of higher gas temperatures in a rotary kiln for mixtures than the gas temperature generated by combustion of diesel. Compared to diesel fuel, by burning fuel WMO50, the flue gas temperature in the rotary kiln increased by about $22 \%$. Most literature data such as $[1,6,19]$ show a slight increase in NO by burning mixtures of waste oils and diesel fuels in internal combustion engines.

\subsubsection{Carbon-Monoxide (CO) Emission}

Variations of $\mathrm{CO}$ emission during combustion of a mixture of WMO with diesel fuel and diesel are shown in Figure 4. CO emissions for WMO diesel fuel mixtures are significantly higher than diesel combustion emissions. The $\mathrm{CO}$ emission for diesel fuel was $0.0032 \%$, and for blends WMO20, WMO25, WMO33 and WMO50, was $0.0064 \%, 0.0086 \%$, $0.0094 \%$ and $0.0124 \%$, respectively. The CO emissions for WMO and its mixtures are higher 
because of poor mixture formation due to less oxygen in the chamber for combustion. In the cited literature $[1,6,19]$ an increase in $\mathrm{CO}$ for all types of tested fuels can be found.

\subsubsection{Carbon-Dioxide $\left(\mathrm{CO}_{2}\right)$ Emission}

Combustion of $\mathrm{WMO}$ and its diesel blends recorded $\mathrm{CO}_{2}$ emissions in the interval of $8.12 \%$ to $9.20 \%$ for $\mathrm{WMO} 20$ and $\mathrm{WMO} 50$, respectively. $\mathrm{CO}_{2}$ emissions for diesel WMO blends are slightly higher than diesel combustion emissions of $7.44 \%$ (Figure 5 ). In the flue gas relative to the volume fraction of $\mathrm{CO}$ for all types of combustion, the $\mathrm{CO}_{2}: \mathrm{CO}$ ratio indicates lower $\mathrm{CO}_{2}$ concentrations for $\mathrm{WMO}$-diesel blends compared to diesel. For combustion of WMO50, $\mathrm{CO}_{2}: \mathrm{CO}=0.74 \cdot 10^{3}: 1$, and for combustion of diesel, $\mathrm{CO}_{2}: \mathrm{CO}=2.32 \times 10^{3}: 1$; they are as expected (Figure 6).

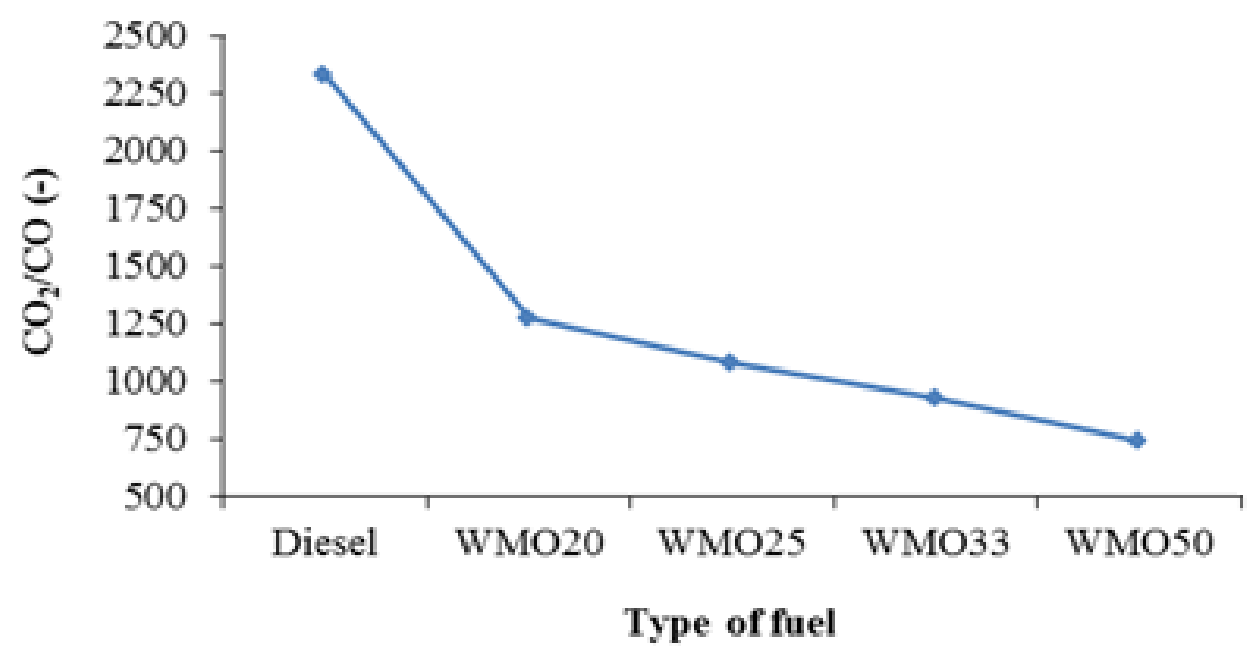

Figure 6. The ratio of emissions $\mathrm{CO}_{2} / \mathrm{CO}$ for different types of fuels.

\subsection{Rinsing the Flue Gases}

The flue gas absorption was performed in the washer (9) with distilled water (Figure 1). The rinsing was performed to determine the composition of the liquid mixture after the combustion process of the various fuels. Parameters determined: sulphates, $\mathrm{pH}$, sulphides, nitrates and nitrites [20]. The results are shown in the diagrams of Figures 7-11. In the washer (9), the presence of all considered parameters was detected. The highest concentration of sulphate $\left(\mathrm{SO}_{4}\right)$ in the washer was observed during WMO20 combustion of $45 \mathrm{mgL}^{1}$, and the lowest in distilled water was less than $2 \mathrm{mg} \mathrm{l}^{-1}$ (Figure 7).

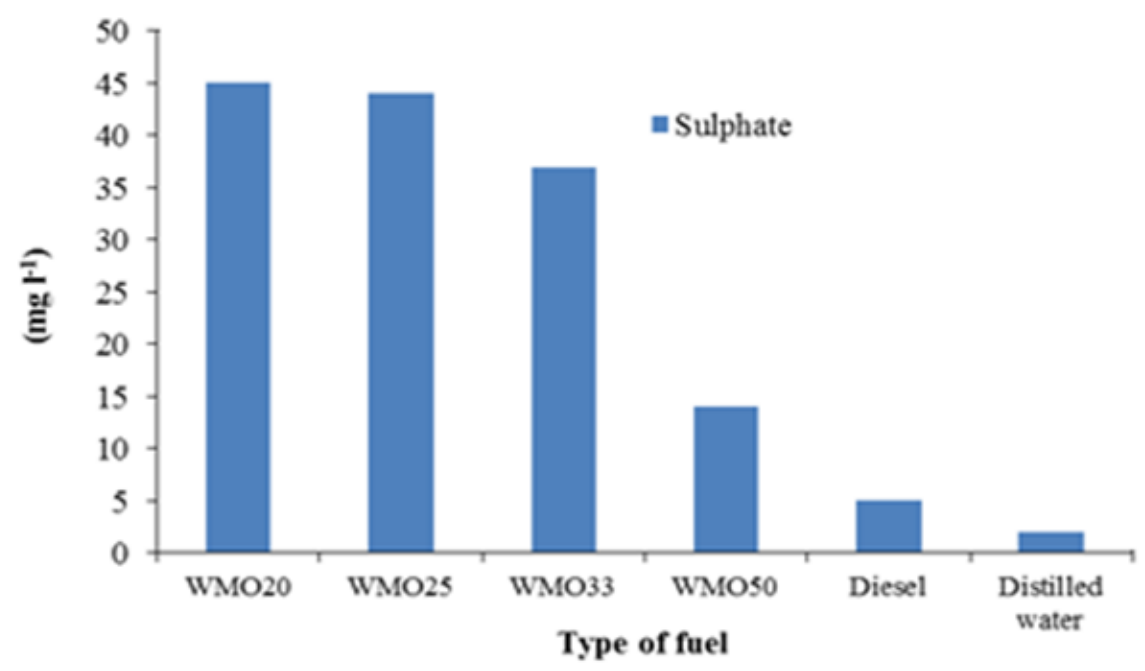

Figure 7. Sulphate fraction in the solution during the flue gas purification for different fuel types. 


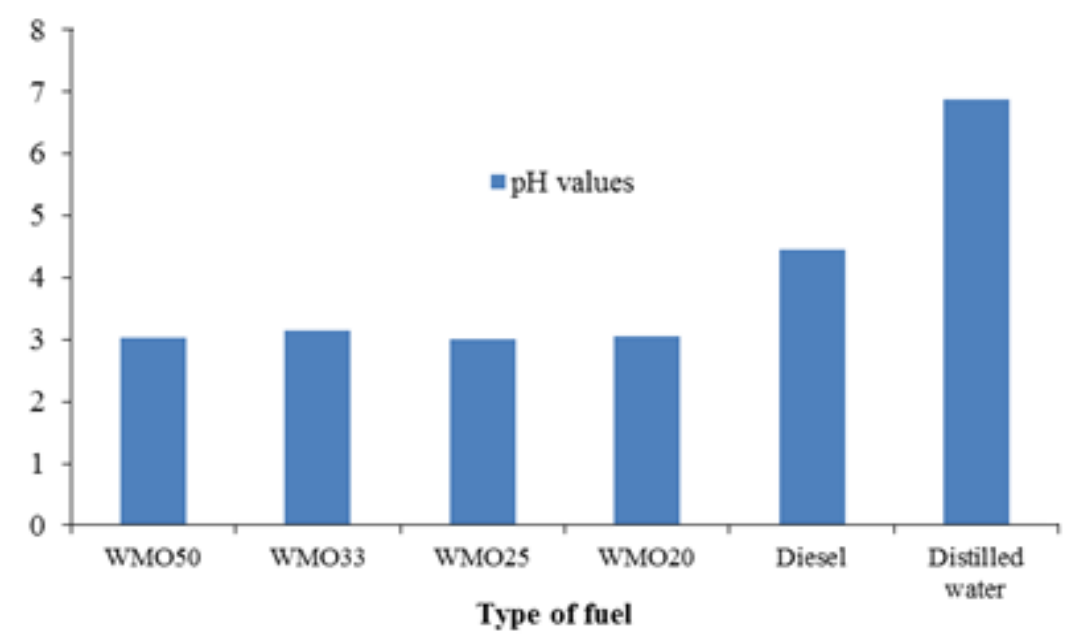

Figure 8. $\mathrm{pH}$ variations in the solution during the flue gas purification for different fuel types.

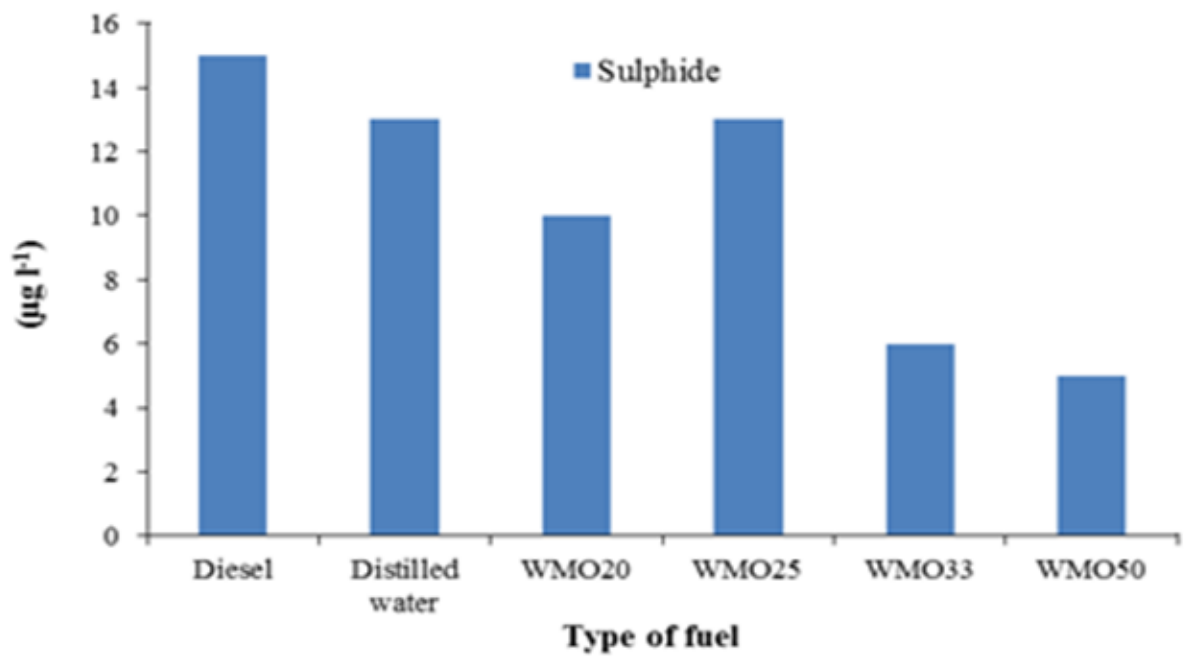

Figure 9. Content of sulphide in solution in flue gas flushing for different types of fuel.

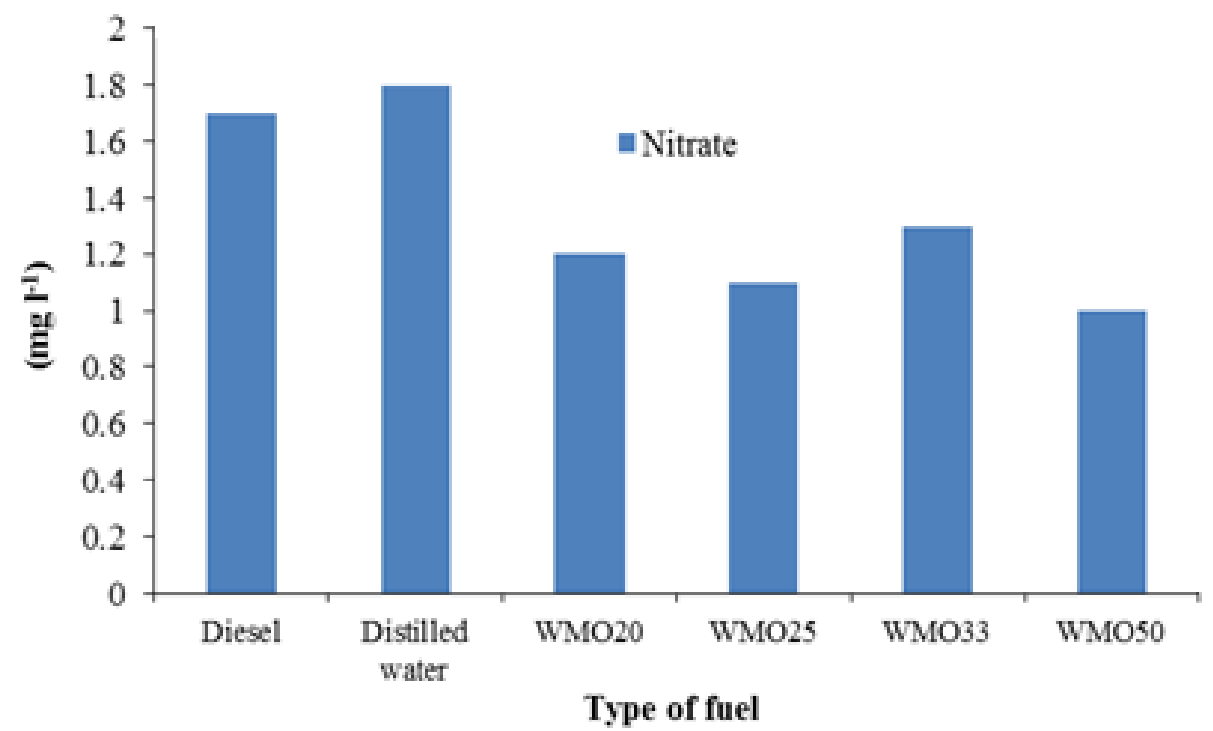

Figure 10. Proportion of nitrate in the solution during washing of the flue gas to different types of fuel. 


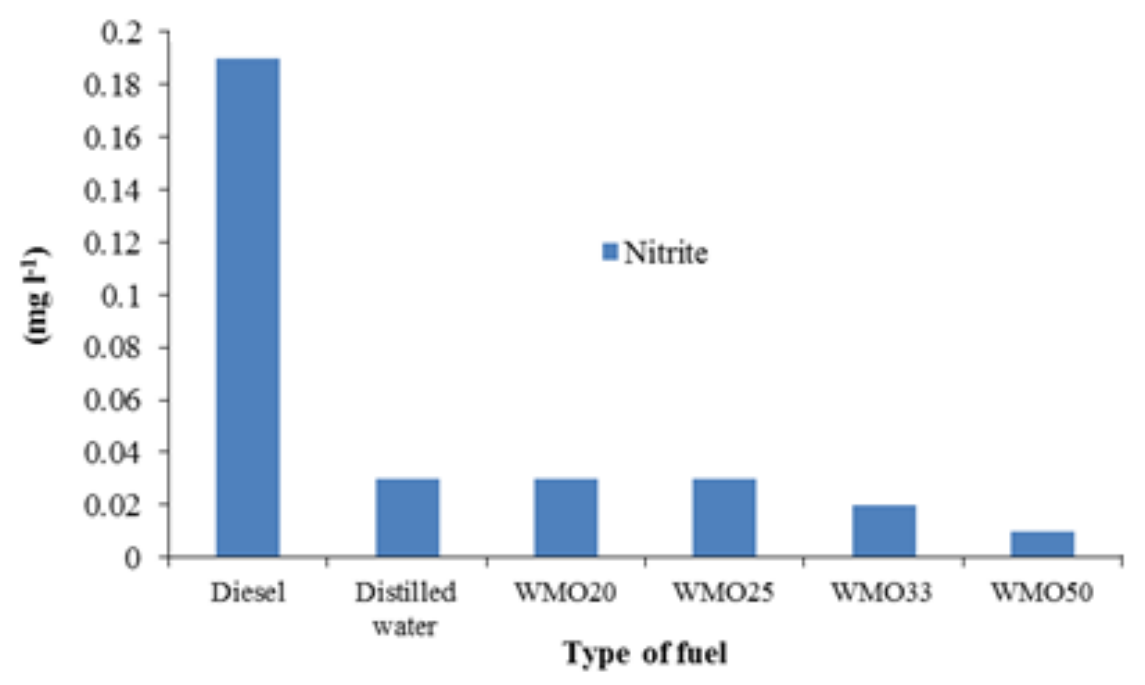

Figure 11. Nitrite content in the rinse for different types of fuel.

This was expected, given the sulphur content of $\mathrm{WMO}$ of $0.15 \%$ and the high excess air ratio of 1.95 during the combustion process. These concentrations of sulphate, when found in the atmosphere, contribute to the formation of acid rain, so that through precipitation, they can degrade the soil and reach groundwater, which has a detrimental effect on the environment. The presence of sulphate in the water increases the acidity of the solution as observed in Figure 8.

Figure 9 shows a decrease in the sulphide in the flush when combusting WMO and its mixtures with respect to diesel. The highest concentrations of sulphide in diesel and distilled water are expected given the physical and chemical properties of diesel and distilled water.

The nitrate content of the solution ranges from $1 \mathrm{mgL}^{-1}$ when using WMO50 fuel to $1.8 \mathrm{mgL}^{-1}$ when using distilled water. The decrease of nitrate in WMO and its mixtures is observed in the yield on diesel and distilled water (Figure 10). All recorded nitrate values in the solution are 20 to 36 times higher than the allowable values of $0.05 \mathrm{mgL}^{-1}$ [21].

The highest nitrite concentration of $0.19 \mathrm{mgL}^{-1}$ was observed when using diesel and was 6.33 times higher than the allowed value of $0.03 \mathrm{mgL}^{-1}$ [21]. The concentration of nitrite when using WMO and its blends with diesel is within the permissible limits of Figure 11.

\section{Conclusions}

Waste motor oil was used as fuel by mixing with diesel fuel in mass proportions of $20 \%, 25 \%, 33 \%$ and $50 \%$. Since these mixtures are close to the properties of diesel fuel in terms of calorific value (Table 2), combustion was performed in a rotary kiln with thermal power of $40 \mathrm{~kW}$ without any difficulties, and the following conclusions were reached:

- The flue gas temperature in the furnace is significantly higher for all WMO and diesel fuel blends compared to diesel, which indicates the efficiency of the input energy;

- Used diesel WMO blends can be used as fuel in low power heat generators, agricultural machinery, low power diesel engines as well as in various branches of the process industry;

- $\quad \mathrm{NO}$ emissions for the used WMO and diesel fuel blends are significantly higher than NO emissions from diesel combustion;

- Emissions of CO mixture used for WMO and diesel fuels are significantly higher than the emissions of $\mathrm{CO}$ produced by burning diesel fuel;

- $\mathrm{CO}_{2}$ emissions are higher for used WMO mixture and diesel fuel than $\mathrm{CO}_{2}$ emissions resulting from the combustion of diesel fuel;

- The $\mathrm{CO}_{2}: \mathrm{CO}$ ratio in the flue gas is lower for $\mathrm{WMO}$ and diesel fuel blends compared to diesel; 
- Absorption of flue gases have recorded concentrations of sulphate, sulphide, nitrate and nitrite and their presence in the flue gas, when found in the atmosphere, can adversely affect the environment. The nitrate concentrations in the solution are much higher than the allowable values and the nitrite concentrations in the solution are much higher than the allowable values for diesel fuel only. Research on fuel blending procedures and the use of mineral additives, as ways to mitigate these problems, are being implemented.

The conclusion is that WMO and its mixtures with diesel fuel can be used as an alternative fuel in different mass ratios in internal combustion engines as well as in various low heat power combustion plants. Taking into account particularly low fuel consumption values obtained for the WMO-diesel fuel ratio, this represents a significant value and reduces additional costs.

Author Contributions: Conceptualization, S.Đ., D.Đ. and M.M.; Methodology, D.Đ., S.Đ. and Z.Ć.; Formal Analysis, S.Đ., D.Đ. and M.M.; Investigation, S.Đ., D.Đ., M.M. and Z.C.; Writing-Original Draft Preparation, S.Đ.; Writing—Review and Editing, D.Đ. and M.M.; Visualization, D.Đ. and T.Đ.; Supervision, S.Đ. All authors have read and agreed to the published version of the manuscript.

Funding: This research had no external funding.

Institutional Review Board Statement: Not applicable.

Informed Consent Statement: Not applicable.

Data Availability Statement: There are no public data on this type of research in Bosnia and Herzegovina, and the results of related research are cited in the literature.

Conflicts of Interest: The authors declare no conflict of interest.

\section{References}

1. Kannan, M.; Saravanan, C.G. Analyzing the characteristics of fuel extracted by catalytic conversion of waste engine oil. Energ. Sources A 2016, 38, 1685-1692. [CrossRef]

2. Krishnakumar, S.; Khan, T.M.Y.; Rajashekhar, C.R.; Soudagar, M.E.M.; Afzal, A.; Elfasakhany, A. Influence of Graphene Nano Particles and Antioxidants with Waste Cooking Oil Biodiesel and Diesel Blends on Engine Performance and Emissions. Energies 2021, 14, 4306. [CrossRef]

3. El-Seesy, A.I.; Hamdy, H.; Ookawara, S. Influence of adding multiwalled carbon nanotubes to waste cooking oil biodiesel on the performance and emission characteristics of a diesel engine: An experimental investigation. Int. J. Green Energy 2019, 16, 901-916. [CrossRef]

4. Djordjic, D.; Djuric, S.; Curguz, Z.; Hadzistevic, M. Experimental revitalisation test of waste transformer oil in Republika Srpska (Bosnia and Herzegovina). J. Environ. Prot. Ecol. 2019, 20, 862-871.

5. Behera, P.; Murugan, S. Combustion, performance and emission parameters of used transformer oil and its diesel blends in a DI diesel engine. Fuel 2013, 104, 147-154. [CrossRef]

6. Saidulu, E.; Dattatreya, G.S.G. Performance evaluation and emission characteristics of a waste transformer oil as an alternative fuel for diesel engine. IJETTCS 2015, 4, 33-41.

7. Mani, M.; Nagarajan, G. Influence of injection timing on performance, emission and combustion characteristics of a DI diesel engine running on waste plastic oil. Energy 2009, 34, 1617-1623. [CrossRef]

8. Mani, M.; Subash, C.; Nagarajan, G. Performance, emission and combustion characteristics of a DI diesel engine using waste plastic oil. Appl. Therm. Eng. 2009, 29, 2738-2744. [CrossRef]

9. Murugan, S.; Ramaswamy, M.C.; Nagarajan, G. The use of tyre pyrolysis oil in diesel engines. Waste Manag. 2008, 28, 2743-2749. [CrossRef]

10. Murugan, S.; Ramaswamy, M.C.; Nagarajan, G. Performance, emission and combustion studies of a DI diesel engine using Distilled Tyre pyrolysis oil-diesel blends. Fuel Process. Technol. 2008, 89, 152-159. [CrossRef]

11. Fuentes, M.J.; Font, R.; Gomez-Rico, M.F.; Martin-Gullon, I. Pyrolysis and combustion of waste lubricant oil from diesel cars: Decomposition and pollutants. J. Anal. Appl. Pyrolysis 2007, 79, 215-226. [CrossRef]

12. Nabi, M.N.; Akhter, M.S.; Rahman, M.A. Waste transformer oil as an alternative fuel for diesel engine. Procedia Eng. 2013, 56, 401-406. [CrossRef]

13. Tajima, H.; Takasaki, K.; Nakashima, M.; Yanagi, J.; Takaishi, T.; Ishida, H.; Osafune, S.; Iwamoto, K. Combustion of Used Lubricating Oil in a Diesel Engine; Kyushu University: Fukuoka, Japan, 2001.

14. Al-Ghouti, M.A.; Al-Degs, Y.S.; Amer, M. Determination of motor gasoline adulteration using FTIR spectroscopy and multivariate calibration. Talanta 2008, 76, 1105-1112. [CrossRef] [PubMed] 
15. Al-Widyan, M.L.; Tashtoush, G.; Abu-Qudais, M. Utilization of ethyl ester of waste vegetable oils as fuel in diesel engines. Fuel Process. Technol. 2002, 76, 91-103. [CrossRef]

16. Al-Widyan, M.L.; Al-Shyoukh, A.O. Experimental evaluation of the transesterification of waste palm oil into biodiesel. Bioresour. Technol. 2002, 85, 253-256. [CrossRef]

17. Djordjevic, B.; Valent, V.; Serbanovic, S. Zbirka Zadataka iz Termodinamike sa Termotehnikom (Exercise Book in Thermodynamics with Thermotechnics); (In Serbian). Faculty of Technology and Metallurgy: Belgrade, Serbia, 2001.

18. Laboratory for Testing Water, Hydrocarbons and Materials. Testing and Measurement Report; INA-Oil Industry: Zagreb, Croatia, 2017.

19. Abdulkerim, Y.; Sehmus, A. The use waste transformer oil as alternative fuel in diesel power generator. Int. J. Automot. Eng. Technol. 2019, 8, 117-124.

20. Laboratory for Monitoring Landfills, Waste Water and Air. Test Report; Faculty of Technical Sciences: Novi Sad, Serbia, 2019.

21. Council of Ministers of Bosnia and Herzegovina. Rule Book, 40; The Official Gazette of Bosnia and Herzegovina: Sarajevo, Bosnia and Herzegovina, 2010. 